\title{
2001-2010 年秦岭森林物候时空变化遥感监测
}

\author{
夏浩铭 ${ }^{1,2}$, 李爱农 ${ }^{1^{*}}$, 赵 伟 ${ }^{1}$, 边金虎 ${ }^{1,2}$, 雷光斌 ${ }^{1,2}$ \\ (1. 中国科学院水利部成都山地灾害与环境研究所,成都 610041；2. 中国科学院大学, 北京 100049)
}

\begin{abstract}
摘 要: 植被物候是陆地生态系统对全球气候变化响应的最佳指示器, 研究其时空变化对深人理解陆面水热过程、 碳循环过程及预测陆地生态系统的时空变化具有重要意义。本文采用2001-2010年MODIS MOD09A1产品,通过 引人 MOD09A1 的时间控制层 DOY(Day of Year)提高 EVI 的时间精度; 采用最大变化速率法和阈值法相结合提取 秦岭森林物候期。结果表明, 随着水热条件变化, 由低海拔至高海拔, 东南向西北, 生长季始期(Start of Growth Season, SOG)逐渐推迟, 集中在第 81 120 d(即从 3 月下旬-4月末); 生长季末期(End of Growth Season, EOG)逐渐提 前, 集中在第270 311 d(10月初-11月上旬); 生长季长度(Length of Growth Season, LOG)逐渐缩短, 集中在 150 230 d。 秦岭森林物候期与海拔关系密切, 海拔每升高 $100 \mathrm{~m}$, SOG 推迟 $2 \mathrm{~d}$, EOG 提前 $1.9 \mathrm{~d}, \mathrm{LOG}$ 缩短 $3.9 \mathrm{~d} 。 2001-2010$ 年, 森林 SOG 提前、EOG 延后和 LOG 延长主要分布于秦岭中高海拔区; SOG 延后、EOG 提前和 LOG 缩短主要分布 在海拔 $1000 \mathrm{~m}$ 以下部分区域。高海拔区物候的年际变化要比低海拔区复杂, $2000 \mathrm{~m}$ 以上区域 SOG 提前、EOG 提 前、LOG 缩短。上述研究结果量化了不同海拔梯度森林的物候差异, 揭示了近 10 年秦岭森林物候的时空格局, 可 为秦岭地区生态环境评价和保护提供科学依据。
\end{abstract}

关键词: EVI; 时间序列谐波分析;物候;时空变化;秦岭

\section{1 引言}

物候学是研究自然界动植物与其所处周期变 化的环境(气候、水文、土壤)之间相互关系的科学 (笂可桢等, 1973; Schwartz, 2003)。植被作为陆地 生态系统的重要组成部分, 是环境条件和年际变化 最直观、最敏感的生物指示器, 其物候的时空变化 与全球气候变化、水循环、碳循环和陆地生态系统 初级生产力息息相关。在近 100 年来气候变暖已成 为事实的背景下 (Peñuelas et al, 2001; 方修琦等, 2002; White et al, 2005; 陈效述等, 2009), 物候学又 重新受到学术界的广泛关注。

传统的物候观测通常采用野外目视观察法, 通 过定点观测不仅耗费大量物力和人力, 而且覆盖面 小, 观测物种有限, 不易开展长时间序列大区域监
测。遥感观测具有覆盖范围广, 连续性强的特点, 是传统物候观测手段的有效补充 (Moulin et al, 1997)。目前采用高时空分辨率遥感数据反演归一 化植被指数(NDVI)监测植被物候期的研究较多, 在 区域乃至全球尺度物候监测研究中已取得一系列 初步成果(Myneni et al, 1997; Eleonora et al, 2001; Piao et al, 2006; 王宏等, 2006; 于信芳等, 2006)。而 NDVI存在高植被覆盖区易饱和、没有考虑背景土 壤噪音和气溶胶对植被指数的影响等缺陷。而增 强植被指数(EVI)避免了高植被覆盖区易饱和的问 题,减少大气和土壤背景影响, 同时在高生物量地 区有更高的敏感性, 与叶面积指数(LAI)线性相关 更高; 且当地表湿度较高时, EVI 比 NDVI的效果要 好很多(Huete et al, 2002), 因此本文选取 EVI 作为 监测物候变化的数据源。

收稿日期: 2014-12; 修订日期: 2015-05。

基金项目: 中国科学院 “百人计划”项目(Y1R2130130); 四川省“千人计划”项目(Y3D1620620); 国家自然科学基金项目 (41271433, 41401425); 中国科学院战略先导性科技专项(XDA05050105); 国际合作创新团队项目(KZZD-EW-TZ06 ; 中国科学院西部之光西部博士资助项目。

作者简介: 夏浩铭(1983-), 河南永城人,博士研究生, 主要从事山地定量遥感研究, E-mail: xiahm2002@163.com。

通讯作者: 李爱农(1974-), 安徽庐江人, 研究员, 主要从事山地定量遥感与山区环境研究, E-mail: ainongli@imde.ac.cn。

引用格式:夏浩铭, 李爱农, 赵伟, 等. 2015. 2001-2010年秦岭森林物候时空变化遥感监测 [J]. 地理科学进展, 34(10): 1297-1305. [Xia H M, Li A N, Zhao W, et al. 2015. Spatiotemporal variations of forest phenology in the Qinling zone based on remote sensing monitoring, 20012010[J]. Progress in Geography, 34(10): 1297-1305.]. DOI: 10.18306/dlkxjz.2015.10.010 
全球变化由千差万别的区域变化构成, 而区域 变化研究的重点将集中在生态脆弱区和自然地理 过渡地带, 如山地、海岸带及水热条件的大梯度过 渡带。秦岭是中国南北方气候和地理的重要分界 线,其南北地理地貌、气候生态差异巨大。有关秦 岭地区植被物候长时间序列时空格局及变化显著 性水平的研究鲜有报道, 仅有的物候研究主要集中 在植物物候定点观测, 很难了解整个秦岭地区植被 物候空间分布特征及长时间序列变化规律。因此, 本文首先改进遥感数据的预处理方法, 提高了 EVI 数据的时间精度; 其次, 采用最大变化速率法和阈 值法相结合提取秦岭森林物候期, 对该区域森林物 候的时空格局进行分析, 并探讨 2001-2010年间物 候的时间变化趋势, 以期为全球变化背景下秦岭生 态环境评价和保护提供科学依据和决策支持。

\section{2 数据与方法}

\section{1 研究区域}

秦岭横亘在中国中部(图 1), 总体与 1 月份 $0^{\circ} \mathrm{C}$ 等温线、 $800 \mathrm{~mm}$ 等降水量线和 $2000 \mathrm{~h}$ 日照时数等 值线基本一致, 是中国南北、湿润与半湿润气候、亚 热带与暖温带的分界线(白红英等, 2012)。广义秦 岭是指长江和黄河流域的分水岭, 西起小陇山, 东 至伏牛山, 南以汉水, 北以渭河为界, 包括甘肃、陕 西、河南三省的 43 个县(张殷波等, 2014)。境内分 布甘肃小陇山, 陕西太白山、熊耳山、华山以及河南
伏牛山等。由于其地形的屏障作用,南北坡形成不 同植被类型带谱, 北坡处在暖温带半湿润区, 基带 为暖温带落叶阔叶林, 南坡处于北亚热带湿润区, 基带为北亚热带落叶阔叶与常绿阔叶混交林(高翔 等, 2012)。区域年均温 $12 \sim 17^{\circ} \mathrm{C}, \geqslant 10^{\circ} \mathrm{C}$ 的年积温为 $3700 \sim 4900^{\circ} \mathrm{C}$, 年均降水量 $600 \sim 1200 \mathrm{~mm}$, 无霜期 200 250 d (蒋冲, 2015)。

\section{2 研究资料}

本文采用美国 LPACC(Land Processes Distributed Active Archive Center) 提供的 2001-2010年秦 岭地区 MOD09A1 和 MCD12Q1 产品 (http://reverb. echo.nasa.gov/reverb/), 其时空分辨率分别为 $8 \mathrm{~d}$ 和 $500 \mathrm{~m}$ 。尽管 MODIS 数据中心提供 $16 \mathrm{~d}$ 合成的植 被指数产品,但是其时间间隔对于物候期的估算研 究来说相对较长。植被类型为 MCD12Q1 产品中 IGBP(国际地圈生物圈计划)全球植被分类系统数 据集。数字高程数据源于中国科学院计算机网络 信息中心国际科学数据镜像网站 (http://www.gscloud.cn)提供的 $90 \mathrm{~m}$ 分辨率的 SRTM产品。

\section{3 研究方法}

\subsubsection{MODIS 陆地表面反射率、EVI}

MODIS(Moderate- resolution imaging spectroradiometer)陆地表面反射率产品(MOD09A1)具有 7 个波段(Jin et al, 2013): 红光波段(620 670 nm)、近红 外波段 1(842 876 nm)、蓝波段(459 479 nm)、绿波 段(545 565 nm)、近红外波段2(841 876 nm)、短波 红外波段 1(1628 1652 nm)、短波红外波段 2(2105

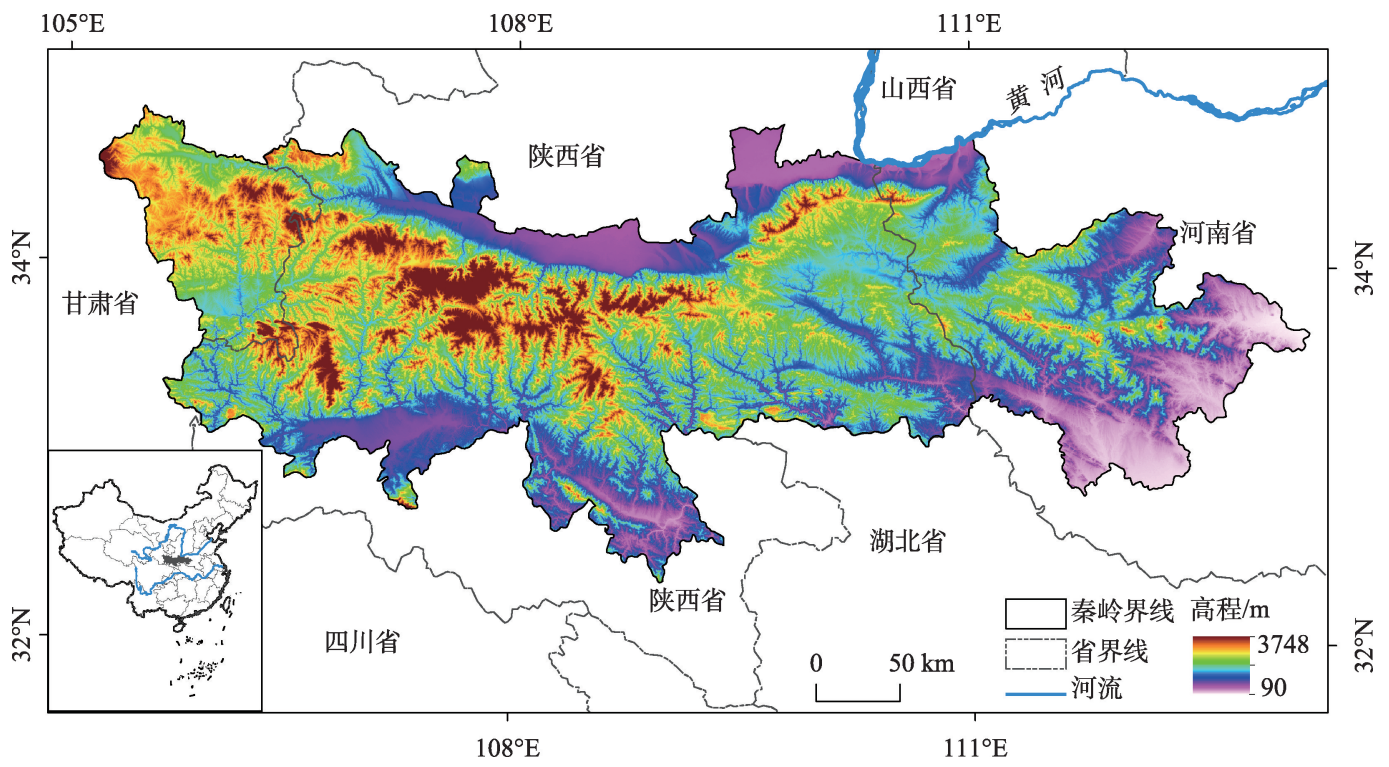

图 1 研究区地理位置和地形图

Fig.1 Geographic location and topography of the study area 
$2155 \mathrm{~nm})$ 。全年有 46幅MOD09A1 影像, $8 \mathrm{~d}$ 合成产 品数据是 $8 \mathrm{~d}$ 中数据质量最好那天的数据。基于 MOD09A1, 根据式(1)可直接获得该影像的 EVI值 (Huete et al, 2002)。由于 MOD09A1 为 $8 \mathrm{~d}$ 合成的 值, 其时间分辨率为 $8 \mathrm{~d}$ 。一般情况下, 已有研究中 基于 MOD09A1 计算的 EVI值通常采用 $8 \mathrm{~d}$ 中的第 一天来标定产品的时间信息, 未考虑产品内具体像 元所对应的时间差异,因此会对估算结果带来一定 的时间偏差。为了消除 $8 \mathrm{~d}$ 时间分辨率在重构 EVI 年时间序列中时间偏差的影响, 本文引人 MOD09A1 产品中的时间控制层 DOY(Day of Year) 层, 使获得 EVI值具体到 $8 \mathrm{~d}$ 中的某一天, 从而提高 EVI时间序列的时间精度。

$$
E V I=2.5 \times \frac{\rho_{\text {NIR }}-\rho_{\text {red }}}{\rho_{\text {NIR }}+6 \times \rho_{\text {red }}-7.5 \times \rho_{\text {blue }}+1}
$$

式中: $\rho_{\mathrm{red}} 、 \rho_{\mathrm{NIR}}$ 和 $\rho_{\text {blue }}$ 分别为红光波段、近红外波 段 1 和蓝光波段的反射率。

由于混交林和落叶阔叶林占研究区森林面积 的 $98.9 \%$ (根据 MCD12Q1 中 IGBP 植被分类图统 计), 因此选取混交林和落叶阔叶林 EVI值的时序曲 线说明引人DOY 层对遥感物候期提取的影响, 图 2 显示: 同一个 $8 \mathrm{~d}$ 的 EVI值, 改进后比改进前整体向 右偏, 改进后的 EVI 时序曲线整体右移, 因此根据 改进前数据提取的遥感物候期整体呈提前趋势, 通 过引人 DOY 层可以消除未改进原始数据造成的物 候期伪提前。图 2 中 “原始 $8 \mathrm{~d}$ EVI 值”、“原始 $8 \mathrm{~d}$ EVI值滤波” 分别为常规方法计算的 EVI 值(时间分 辨率为 $8 \mathrm{~d}$ )和经过滤波后重采样为 $1 \mathrm{~d}$ 时间分辨率 的 EVI 曲线。“改进 $1 \mathrm{~d}$ EVI值”、“改进 $1 \mathrm{dEVI}$ 值滤
波” 分别为引人 DOY 层后计算的 EVI 值(时间分辨 率为 $1 \mathrm{~d}$ ) 和经过滤波后重采样为 $1 \mathrm{~d}$ 时间分辨率的 EVI曲线。

\subsection{2 遥感数据的预处理}

尽管 MOD09A1 经过严格的预处理,采用最大 值合成法(MVC)消除太阳高度角、大气、云、气溶胶 等对 EVI数据的影响, 使获得的影像在周期内最接 近实际情况，但亚像元内仍存在残余云、长时间云 及云皬等“噪声”,随机出现的噪声使得数据的时间 序列曲线呈锯齿状变化,其形态波动很大, 季节变 化趋势不明显,也无法进行各种信息提取和趋势分 析(丁明军等, 2012; 侯学会等, 2013)。因此必须对 EVI时序数据进行去噪、平滑处理, 本文采用时间序 列谐波分析法(HANTS)对数据进行滤波处理。

时间序列谐波分析法是一种有效的植物物候 分析方法,这种方法全面考虑植被生长周期的规律 性和数据本身的双重特点, 能够真实有效地反映曲 线周期性变化规律(Roerink et al, 2000; 于信芳等, 2006; 丁明军等, 2012)。HANTS 算法参数的设置 为: 频率为 2 , 曲线匹配國值为 500 , 剩余点个数为 16 个。用HANTS 对 $8 \mathrm{~d}$ 合成EVI重采样为 $1 \mathrm{~d}$ 的时 间序列数据, 便于对秦岭森林物候期的提取和数据 验证。滤波前后效果如图 2 所示。

\subsection{3 森林物候参数的提取方法}

目前,已有学者针对植被指数曲线发展了不同 的遥感物候期提取方法,包括:阈值法(Jonsson et al, 2002; 刘玲玲等, 2012; 宋春桥等, 2012; Høgda et al, 2013)、曲线拟合法(Duchemin et al, 1999)、最大变化 速率法(Piao et al, 2006; 丁明军等, 2012)、累积频率
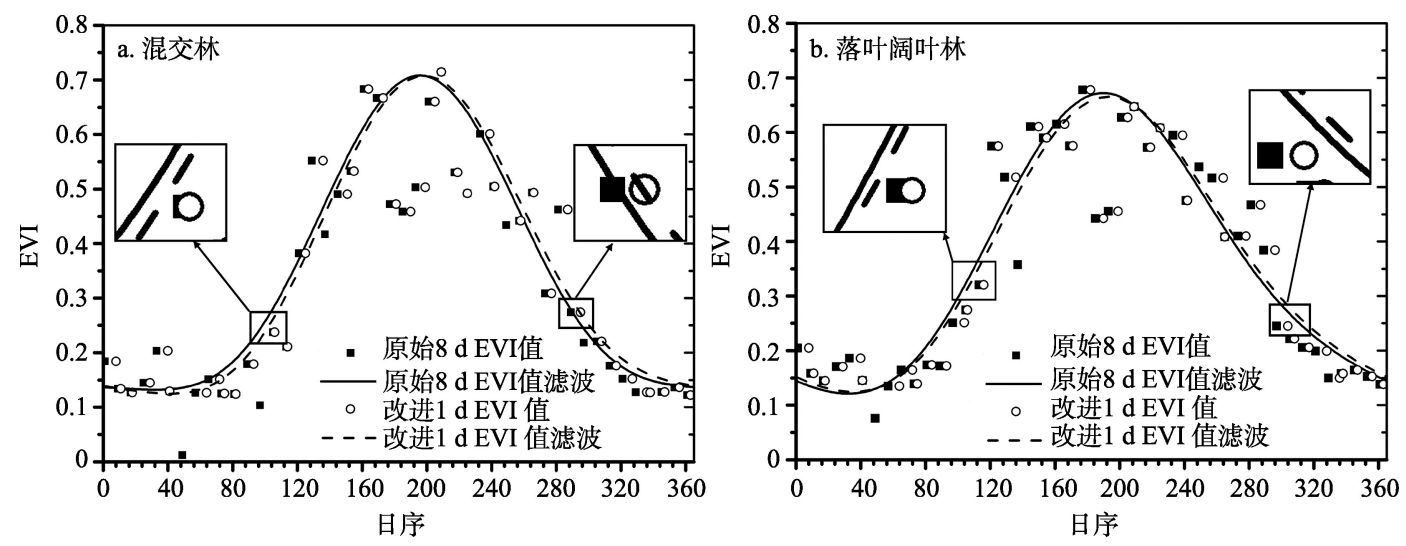

图 2 2009年混交林(a)和落叶阔叶林(b)EVI时序曲线平滑前后对比

Fig.2 Enhanced vegetation index (EVI) time series of mixed forest (a) and deciduous broadleaf forest (b) before and after filtering (Year: 2009) 
法(侯学会等, 2014)和经验回归法 (Moulin et al, 1997)等, 但尚无一种方法被普遍接受(White et al, 2009)。在综合考虑已有方法的基础上, 本文采用 最大变化速率法和阈值法相结合的方法(Piao et al, 2006; 丁明军等, 2012), 提取秦岭森林物候期。其 步骤如下: 首先, 计算日 EVI(改进 $1 \mathrm{dEVI}$ ) 10 年的 平均值, 通过平滑可获得多年平均的 EVI 时间序列 曲线; 其次, 根据该森林生长曲线分别计算森林生 长和衰退期间相邻时间点 EVI变化的绝对值最大 值, 作为生长季始期(Start of Growth Season, SOG) 和生长季末期(End of Growth Season, EOG)发生的 EVI 阈值; 最后, 利用 Hants 平滑可获得每年日 EVI 变化曲线, 利用 SOG 和 EOG 的 EVI阈值, 确定每年 森林的 SOG 和 $\mathrm{EOG}$ 值; 二者差值即为生长季长度 (Length of Growth Season, LOG)。

\section{3 结果与分析}

\section{1 物候期的空间分布}

植被 EVI 的多年平均值可以反映其多年的平 均生长状况。因此, 为了研究近 10 年秦岭森林物候 期的空间分布, 根据式(2)逐象元获取近 10 年 EVI 的均值, 并对均值曲线进行平滑处理, 利用最大变 化速率法提取每个象元的物候期 (SOG、EOG 和 LOG)和阈值(SOG、EOG)。

$$
\overline{E V I}=\left(\sum_{i=1}^{n} E V I_{i}\right) / n
$$

式中: $i \in[1,46], n=46$ 表示年影像数; $E V I_{i}$ 为第 $i$ 幅影 像的 EVI值。

山地高度导致秦岭南北的气候类型不同, 使得 不同海拔梯度及南北坡显现不同物候特征。秦岭 森林近 10 年平均物候期空间分布格局见图 3 , 其中 研究区空白部分为 IGBP 分类中除森林之外的其他 类型(下同)。

从低海拔到高海拔, 东南向西北 SOG 依次推 迟, EOG 依次提前, LOG 逐渐缩短, 这较好地体现 了地形和气候的地域分异规律。从图 3a可以看出, 秦岭 94.2\%森林的 SOG 出现在第 81 120 天(日序, 即 Day of Year, 简称 DOY, 下同)之间, 即 3 月下旬和 4 月。从空间分布格局看, 研究区东南部生长开始 较早, 主要集中在第 70 100天(即 3 月上旬-4月上 旬)逐步开始展叶、生长。研究区中北部由于海拔 较高, 主要集中第100 120天(即在 4 月中下旬)森林
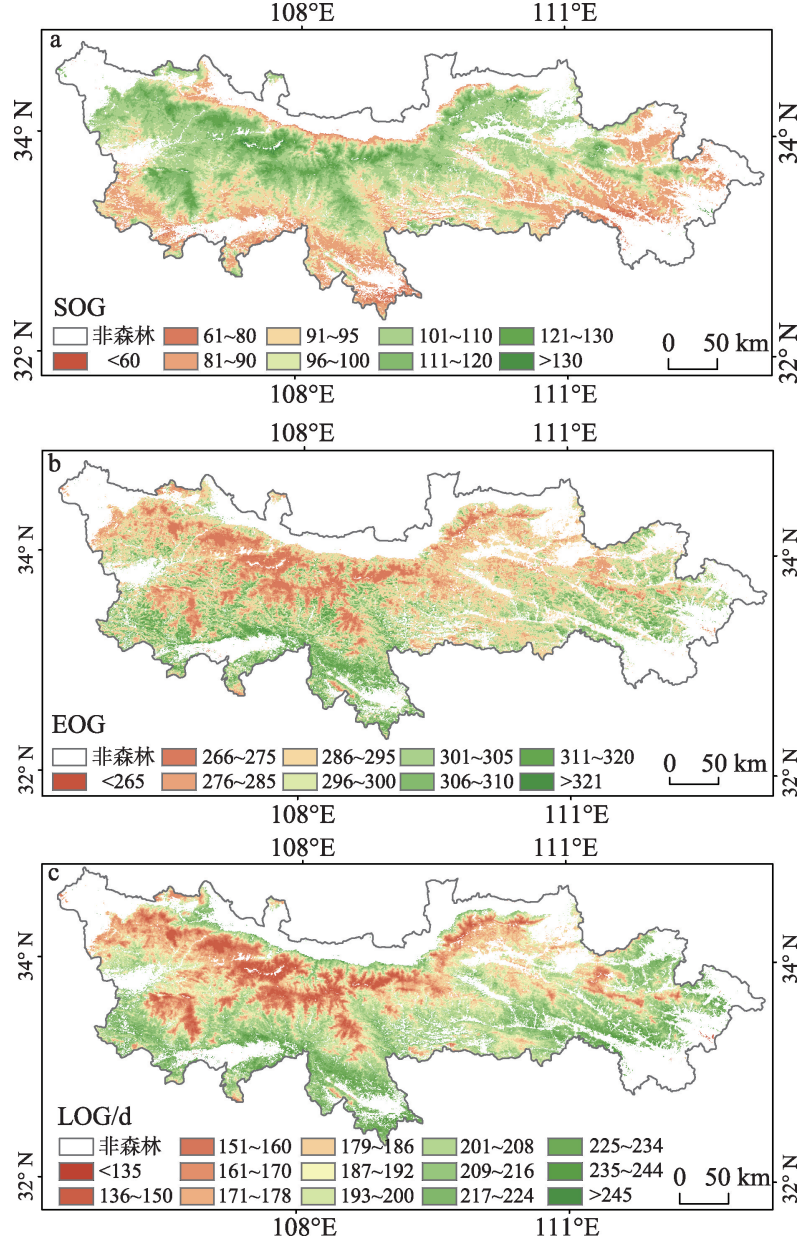

图 3 秦岭森林物候期多年均值的空间分布; DOY 为日序

Fig.3 Spatial distribution of forest average phenology in the Qinling zone; DOY is the Day of Year

逐步开始展叶、生长。海拔较高的太白山地区,生 长季开始的更晚, 在第 $120 \mathrm{~d}$ 以后(即 5 月上旬)逐步 开始展叶、生长。

从图 $3 \mathrm{~b}$ 可以看出, $98 \%$ 的森林 $\mathrm{EOG}$ 出现在第 270 311 天, 即秦岭森林落叶期主要集中在 10 月初 至11月上旬。从空间分布格局来看, 南部及东南部 生长季结束较晚, 主要集中在第 300 天以后(即在 11 月份)。中北部地区由于海拔较高, 生长季结束较 早, 集中在第265 300天(即 9 月下旬)逐步停止生 长。海拔较高的太白山地区, 森林生长季结束更 早, 9 月中旬逐步停止生长。

从图 3c 可以看出, $90 \%$ 的森林 $\mathrm{LOG}$ 主要集中 在150 230天。从空间分布格局来看, 东南部及海 拔较低区域 LOG 较长, 西北部及海拔较高区域 LOG 较短。 
秦岭森林物候期与海拔关系密切, 随海拔升高 $100 \mathrm{~m}$, SOG 推迟 $1.99 \mathrm{~d}$, EOG 提前 $1.92 \mathrm{~d}$, LOG 缩短 $3.92 \mathrm{~d}$ (图 4)。从图 4a可以看出, 海拔 $1500 \mathrm{~m}$ 以下区 域, 相同海拔高度 SOG 振幅比较大, 由于秦岭的阻 挡作用, 导致秦岭南北的水热条件差异较大, 所以 秦岭南北相同海拔地区, SOG 差异较大。从图 $4 \mathrm{~b}$ 可以看出,海拔 $2200 \mathrm{~m}$ 以下区域, 随海拔升高 $\mathrm{EOG}$ 下降明显, 海拔 $2200 \mathrm{~m}$ 以上区域 $\mathrm{EOG}$ 趋于平缓。 图 $4 \mathrm{c}$ 显示, 海拔 $2200 \mathrm{~m}$ 以下区域,随海拔高度升高 LOG 缩短速度较快, 海拔 $2200 \mathrm{~m}$ 以上区域 $\mathrm{LOG}$ 变 化速度较慢。可见, 高海拔地区森林物候期振幅变 小, 这可能与高海拔区域只存在于秦岭的主峰区, 南北水热差异不大有关。

\section{2 物候期的年际变化}

为了研究秦岭近 10 年森林物候期变化趋势, 根 据式(3)逐像元计算生长季始期、末期和长度的年变 化率(Slope), 年变化率反映物候期的年际增加 $(>0$, 即始期延后、末期延后或生长季变长)和减小 $(<0$, 即 始期提前、末期提前或生长季缩短 $)$ 的趋势。计算 公式为:

$$
\text { Slope }=\frac{n \sum_{i=1}^{n}\left(i \times T_{i}\right)-\sum_{i=1}^{n} i \sum_{i=1}^{n} T_{i}}{n \times \sum_{i=1}^{n} i^{2}-\left(\sum_{i=1}^{n} i\right)^{2}}
$$

式中: Slope 表示年变化率, $i \in[1,10], n=10$ 表示年数, $T_{i}$ 为森林第 $i$ 年的物候始期、末期或长度。

图 5a、5d显示生长季始期的变化趋势。从中可 以看出, 该区域以 $-1 \mathrm{~d}$ 为中心呈近似正态分布, 总 体呈提前趋势。 $81 \%$ 的森林生长季始期变化幅度 在 $-3 \sim 2 \mathrm{~d} / \mathrm{a}$ 。其中, $70 \%$ 的森林生长季始期提前。 提前的区域主要分布在中西部和海拔 $1000 \mathrm{~m}$ 以上 的中高海拔区域。29\%的生长季始期延后, 延后区 主要位于秦岭东部易受人类干扰的低海拔区 (海拔 500 1000 m)。

图 5b、5e 显示生长季末期的变化趋势。从中可 以看出, 该区生长季末期以 $0.2 \mathrm{~d}$ 为中心成正态分 布, 总体延后趋势不明显。9 $1.8 \%$ 的森林生长季末 期变化幅度为 $-2 \sim 3 \mathrm{~d} / \mathrm{a}$ 。其中, 森林生长季结束时 间延后和提前的区域分别占有效像元的 $52.2 \%$ 和 $39.4 \%$, 延后区域主要分布在中高海拔区。森林生 长季结束时间提前的区域, 主要分布在易受人类干 扰低海拔区(海拔 500 1000 m) 和海拔 $2000 \mathrm{~m}$ 以上
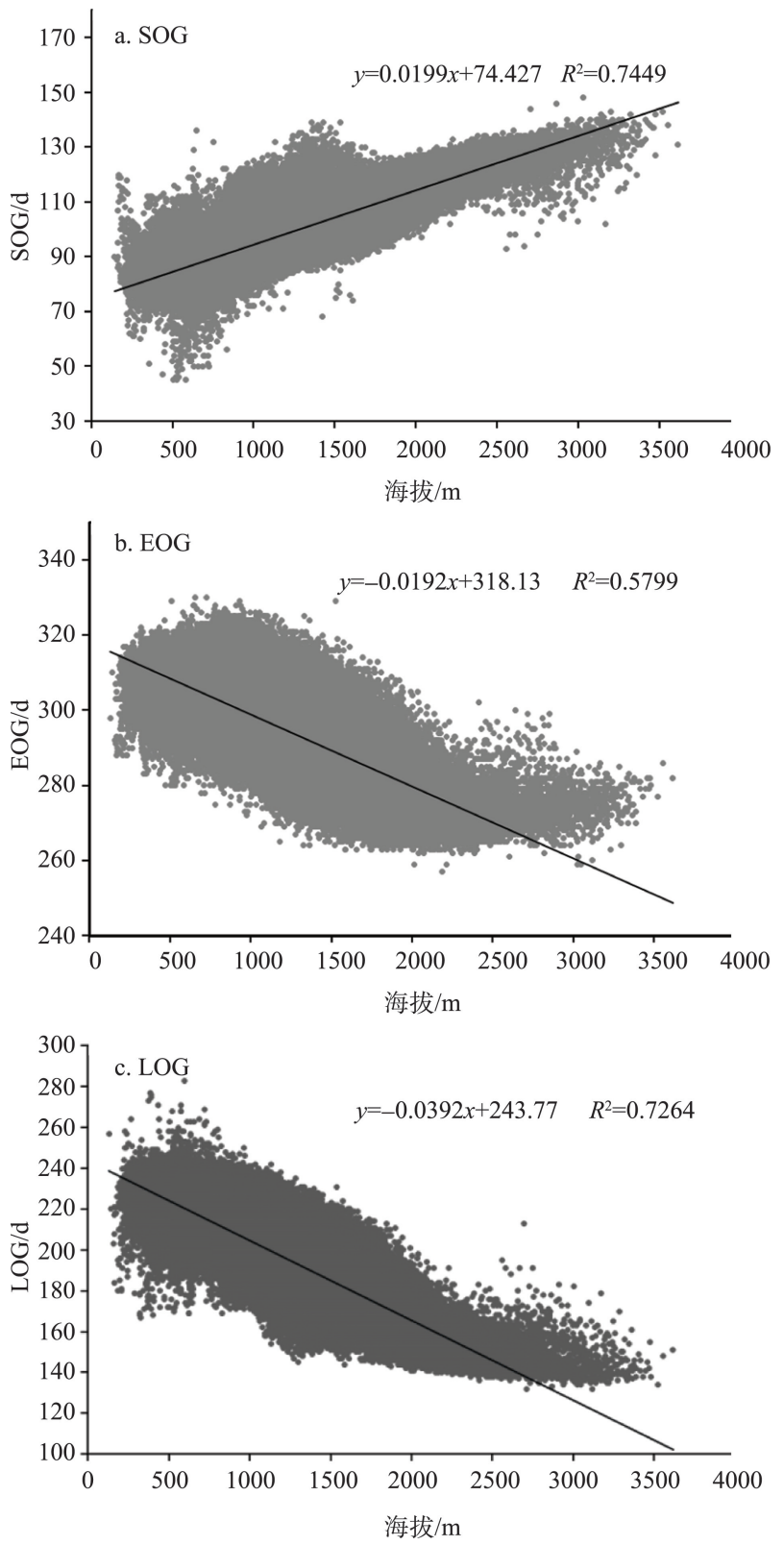

图 4 2001-2010年秦岭森林物候始期、末期及生长季长度 均值与海拔之间的关系

Fig.4 Changes in the mean of forest's start of growth season (SOG) (a), end of growth season (EOG) (b), and length of growth season (LOG) (c) along the altitude gradient in the Qinling zone, 2001-2010

高海拔区。

生长季末期减去生长季始期,得到生长季长 度。图 5c、5f 显示生长季末期变化趋势。可以看出 该区生长季长度以 $1 \mathrm{~d}$ 为中心成正态分布, 总体呈 延长的趋势。 $87.5 \%$ 的森林生长季长度变化幅度 为 $-2 \sim 4 \mathrm{~d} / \mathrm{a}$ 。其中, $58.8 \%$ 的森林物候生长季延长, 主要分布于中高海拔区。 $28.6 \%$ 的生长季长度缩 

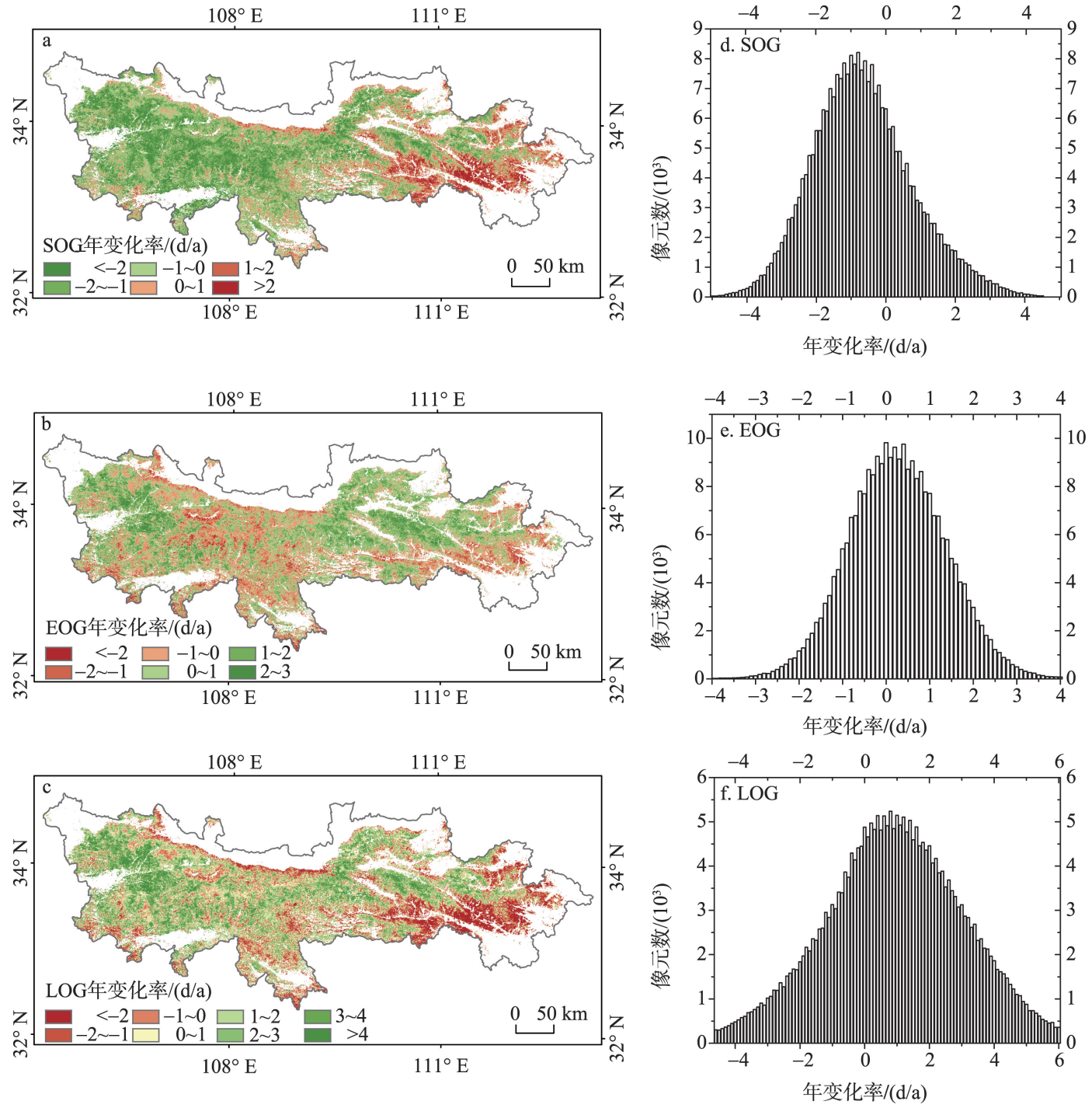

图 5 2001-2010年秦岭森林物候期年际变化趋势图

Fig.5 Spatial distribution of interannual change trend of forest phenology in the Qinling zone, 2001-2010

短, 主要分布在高海拔区和易受人类干扰低海拔区 (海拔 500 1000 m)。

\section{3 遥感物候期的精度验证}

由于秦岭地区地面物候观测数据较少, 结合中 国物候观测网西安站木本植物物候观测数据和已 有学者的研究成果对研究结果进行侧面验证。根 据中国物候观测网西安植物园定位研究站获得的 2001-2010年6种落叶乔木(毛白杨 Populus tomentosa、垂柳 Salix babylonica、榆树 Ulmus pumila、构 树 Broussonetia papyrifera、山桃 Prunus davidiana、 刺槐 Robinia pseucdoacacia) 和 2 种落叶灌木 (桑树 Morus alba、紫荆Cercis chinensis)物候期进行统计, 西安站的平均展叶盛期为 $95.9 \mathrm{~d}$, 叶全变色期为 $309 \mathrm{~d}$ (贺映娜等, 2012)。陈效述等(2008)统计的西
安站树木变绿初日为一年中的第 $67 \mathrm{~d}$, 调落期初日 为一年中的第 $257 \mathrm{~d}$ 。贺映娜(2012)统计的西安站 1998-2008 年期间代表性 8种木本植物的展叶盛期 为一年中的第 $96.5 \mathrm{~d}$, 叶全部变色期为一年中的第 $308.8 \mathrm{~d}$ 。李淑娟等(2013)根据西安植物园和曲江风 景区各公园的 1986-2010 年间的物候观测结果统 计, $37.7 \%$ 的植物 3 月份开始展叶, $61.6 \%$ 的植物 4 月 份开始展叶, $67.6 \%$ 的植物 9 月份开始变色落叶, $32.4 \%$ 的植物变色于 10 月。这与本文得出的秦岭 94.2\%树木的 SOG 出现在第 81 120 d 之间, 98\%树 木的 EOG 出现在第 270 311 d 之间的结果一致。 说明本文利用 MODIS EVI时序数据获取秦岭森林 物候期具有一定的可靠性, 与地面观测数据具有一 定可比性,能够反映研究区森林的物候特征。 


\section{4 讨论}

遥感可以宏观上监测大区域物候现象的变化, 文中采用最大变化速率法获得的是地表植被绿度 变化最剧烈的时间, 其表达的是植被生长或衰退速 率最快的时间,与地面物候观测指标(发芽、展叶、 变色等)未必相同。另外, 遥感监测的物候期是像 元尺度的整体物候期,单个像元涵盖很多物种。而 地面观测数据只是单个物种的、单站点的数据, 与 像元尺度上的遥感物候期相比较, 存在空间尺度的 扩展问题,使得验证的精度受到限制。因此,发展 一种合理的空间尺度转换方法, 以便地面观测数据 验证遥感物候期, 也是未来重点的研究方向。

遥感监测物候的传感器在空中获取地表信息, 在获取数据过程中受到太阳高度角、大气、云、气溶 胶等因素的影响,并且这些影响因素具有很大的时 空变化特征。所以遥感监测物候的准确性高度依 赖卫星数据的质量、数据的重构合理性及提取物候 方法的有效性(丁明军等, 2012)。

植被物候期的变化是对气候变化的响应, 周旗 等(2011)对秦岭南北近 60 年的气温和热量资源研 究表明: 1993 年后秦岭南北气候增暖显著。白红英 等(2012)对近 50 年来秦岭 1 月份 $0^{\circ} \mathrm{C}$ 等温线变化研 究表明, 1993 年是气温明显上升的突变点,突变后 比突变前 1 月 $0^{\circ} \mathrm{C}$ 等温线上升了 $113.82 \mathrm{~m}$ 。气温升 高侧面验证了本文的结论: 秦岭中高海拔地区植被 生长季总体呈延长趋势。秦岭低海拔区生长季缩 短可能与低海拔地区森林像元混杂有栽培植被有 关。因为秦岭地区栽培植被主要种植在海拔 984 $1375 \mathrm{~m}$ 低山缓坡和低山河谷垦殖带 (朱晓勤等, 2006)。丁明军等(2012)研究青藏高原物候变化时 也发现, 低海拔区物候变化不明显, 可能与人类活 动有关。高海拔区物候的年际变化要比低海拔区 复杂(丁明军等, 2012), 秦岭高海拔区物候变化也体 现出复杂性, 如 SOG 提前, EOG 也呈提前趋势, 造 成这种趋势的因素还有待于进一步研究。气象因 子与植被的生长密切相关, 如何定量探讨气象因子 (如气温、降水、日照时数等)对植被物候期的影响, 是下一步工作的重点。

\section{5 结论}

秦岭森林物候多年均值的时空格局与该区域 的水热条件关系密切。由东南向西北,低海拔向高
海拔区, 生长季始期逐渐推迟, 生长季末期逐渐提 前, 生长季长度逐渐缩短。秦岭植被生长季比较集 中,一般在第 81 120 d(即 3 月下旬-4 月末)开始, 在第 270 311 d(10月初-11月上旬)结束, 其生长季 长度集中在 150 230 d; 秦岭森林物候期与海拔关 系密切, 海拔每升高 $100 \mathrm{~m}$,生长季始期推迟 $1.99 \mathrm{~d}$, 生长季末期提前 $1.92 \mathrm{~d}$, 生长季长度缩短 $3.92 \mathrm{~d}$ 。

近 10 年秦岭 $70 \%$ 的森林生长季始期呈提前趋 势, 主要分布在研究区中西部和 $1000 \mathrm{~m}$ 以上的中高 海拔区域。29\%的森林生长季始期延后,主要集中 于东部和易受人类干扰的部分低海拔区(海拔 500 $1000 \mathrm{~m}$ )。生长季末期只有 $52.2 \%$ 的区域呈延后趋 势, 主要位于中高海拔区; 高海拔区 (2000 m 以上) 和易受人类干扰低海拔区(海拔 500 1000 m) 生长 季末期提前。生长季长度整体呈延长趋势, 延长区 主要分布在中高海拔区 ; 高海拔区 (2000 $\mathrm{m}$ 以上)和 易受人类干扰低海拔区(海拔 500 1000 m)生长季 长度缩短。高海拔区物候的年际变化更为复杂, 其 原因还有待于深人研究。

\section{参考文献(References)}

白红英, 马新萍, 高翔, 等. 2012. 基于 DEM 的秦岭山地 1 月 气温及 $0^{\circ} \mathrm{C}$ 等温线变化 $[\mathrm{J}]$. 地理学报, 67(11): 14431450. [Bai H Y, Ma X P, Gao X, et al. 2012. Variations in January temperature and $0^{\circ} \mathrm{C}$ isothermal curve in Qinling Mountains based on DEM[J]. Acta Geographica Sinica, 67(11): 1443-1450.]

陈效述, 韩建伟. 2008. 我国东部温带植物群落的季相及其时 空变化特征 [J]. 植物生态学报, 32(2): 336-346. [Chen X Q, Han J W. 2008. Seasonal aspect stages of plant communities and its spatial-temporal variation in temperate eastern China[J]. Journal of Plant Ecology, 32(2): 336-346.]

陈效述, 王林海. 2009. 遥感物候学研究进展 [J]. 地理科学进 展, 28(1): 33-40. [Chen X Q, Wang L H. 2009. Progress in remote sensing phenological research[J]. Progress in Geography, 28(1): 33-40.]

丁明军, 张镱锂, 孙晓敏, 等. 2012. 近 10 年青藏高原高寒草 地物候时空变化特征分析 [J]. 科学通报, 57(33): 31853194. [Ding M J, Zhang Y L, Sun X M, et al. 2012. Spatiotemporal variation in alpine grassland phenology in the Qinghai- Tibetan Plateau from 1999 to 2009[J]. Chinese Science Bulletin, 58(3): 396-405.]

方修琦, 余卫红. 2002. 物候对全球变暖响应的研究综述 [J]. 地球科学进展, 17(5): 714-719. [Fang X Q, Yu W H. 2002. Progress in the studies on the phenological responding to global warming[J]. Advances in Earth Science, 17 (5): 714-719.] 
高翔, 白红英, 张善红, 等. 2012. 1959-2009年秦岭山地气候 变化趋势研究[J]. 水土保持通报, 32(1): 207-211. [ Gao X, Bai H Y, Zhang S H, et al. 2012. Climatic change tendency in Qinling Mountains from 1959 to 2009[J]. Bulletin of Soil and Water Conservation, 32(1): 207-211]

贺映娜. 2012. 秦岭植被物候期及遥感生长季的变化研究 [D]. 西安: 西北大学. [He Y N. 2012. Research on the variatition of vegetation phenology in Qinling Moutain base on Remote Sensing and in situ obersation[D]. Xi'an, China: Northwest University.]

侯学会, 牛铮, 高帅, 等. 2013. 基于 SPOT-VGT NDVI 时间序 列的农牧交错带植被物候监测 [J]. 农业工程学报, 29 (1): 142-150. [Hou X H, Niu Z, Gao S, et al. 2013. Monitoring vegetation phenology in farming-pastoral zone using SPOT-VGT NDVI data[J]. Transactions of the Chinese Society of Agricultural Engineering, 29(1): 142-150.] 侯学会, 牛铮, 高帅. 2014. 近十年中国东北森林植被物候遥 感监测 $[J]$. 光谱学与光谱分析, 34(2): 515-519. [ Hou X H, Niu Z, Gao S. 2014. Phenology of forest vegetation in northeast of China in ten years using remote sensing[J]. Spectroscopy and Spectral Analysis, 34(2): 515-519.]

蒋冲, 穆兴民, 马文勇, 等. 2015. 秦岭南北地区绝对湿度的 时空变化及其与潜在蒸发量的关系 [J]. 生态学报, 35 (2): 378-388. [Jiang C, Mu X M, Ma W Y, et al. 2015. Spatial and temporal variation of absolute humidity and its relationship with potential evaporation in the northern and southern regions of Qinling Mountains[J]. Acta Ecologica Sinica, 35(2): 378-388.]

李淑娟, 刘雅莉. 2013. 西安主要季色叶植物观赏特征及物 候图谱研究初报 [J]. 西北林学院学报, 28(2): 42-47. [Li S J, Liu Y L. 2013. Ornamental characteristics and phenograms of plant leaf color in the main seasons in Xi'an[J]. Journal of Northwest Forestry University, 28 (2): 42-47.]

刘玲玲, 刘良云, 胡勇. 2012. 1982-2006 年欧亚大陆植被生 长季开始时间遥感监测分析 [J]. 地理科学进展, 31(11): 1433-1442. [Liu L L, Liu L Y, Hu Y. 2012. Assessment and intercomparison of satellite- derived start- of season (SOG) measures in Eurasia for 1982-2006[J]. Progress in Geography, 31(11): 1433-1442.]

宋春桥, 游松财, 柯灵红, 等. 2012. 藏北高原典型植被样区 物候变化及其对气候变化的响应 [J]. 生态学报, 32(4): 1045-1055. [Song C Q, You S C, Ke L H, et al. 2012. Phenological variation of typical vegetation types in northern Tibet and its response to climate changes[J]. Acta Ecologica Sinica, 32(4): 1045-1055.]

王宏, 李晓兵, 莺歌, 等. 2006. 基于 NOAA NDVI 的植被生 长季模拟方法研究 [J]. 地理科学进展, 25(6): 21-32. [Wang H, Li X B, Ying G, et al. 2006. The methods of simulating vegetation growing season based on NOAA NDVI[J]. Progress in Geography, 25(6): 21-32.]

于信芳, 庄大方. 2006. 基于 MODIS NDVI 数据的东北森林 物候期监测 [J]. 资源科学, 28(4): 111-117. [Yu X F, Zhuang D F. 2006. Monitoring forest phenophases of northeast China based on MODIS NDVI data[J]. Resources Science, 28(4): 111-117.]

张殷波, 郭柳琳, 王伟, 等. 2014. 秦岭重点保护植物丰富度 空间格局与热点地区 [J]. 生态学报, 34(8): 2109-2117. [Zhang Y B, Guo L L, Wang W, et al. 2014. Spatial distribution patterns of species richness and hotspots of protected plants in Qinling Mountain[J]. Acta Ecologica Sinica, 34(8): 2109-2117.]

周旗, 市娟娟, 郑景云. 2011. 秦岭南北 1951-2009年的气温 与热量资源变化 [J]. 地理学报, 66(9): 1211-1218. [Zhou Q, Bian J J, Zheng J Y. 2011. Variation of air temperature and thermal resources in northern and southern regions of the Qinling Mountains from 1951 to 2009[J]. Acta Geographica Sinica, 66(9): 1211-1218.]

朱晓勤, 刘康, 秦耀民. 2006. 基于 GIS 的秦岭山地植被类型 与环境梯度的关系分析 [J]. 水体保持学报, 20(5): 192196. [Zhu X Q, Liu K, Qin Y M. 2006. GIS-based study of vegetation- environment gradient relationship in Qinling Mountain[J]. Journal of Soil and Water Conservation, 20(5): 192-196.]

竺可桢, 宛敏渭. 1973. 物候学 [M]. 北京: 科学出版社. [Zhu K Z, Wan M W. 1973. Phenology[M]. Beijing, China: Science Press.]

Duchemin B, Goubier J, Courrier G. 1999. Monitoring phenological key stages and cycle duration of temperate deciduous forest ecosystems with NOAA/AVHRR data[J]. Remote Sensing of Environment, 67(1): 68-82.

Eleonora R, Akihoko K, Ketut W, et al. 2001. NDVI-derived length of the growth period estimations for different vegetation types in Monsoon Asia[J]. IECI Chapter Japan Series, 3: 106-109.

Høgda K A, Tømmervik H, Karlsen S R. 2013. Trends in the start of the growing season in fennoscandia 1982-2011[J]. Remote Sensing, 5(9): 4304-4318.

Huete A, Didan K, Miura T, et al. 2002. Overview of the radiometric and biophysical performance of the MODIS vegetation indices[J]. Remote Sensing of Environment, 83(12): $195-213$.

Jin C, Xiao X M, Merbold L, et al. 2013. Phenology and gross primary production of two dominant savanna woodland ecosystems in Southern Africa[J]. Remote Sensing of Environment, 135: 189-201.

Jonsson P, Eklundh L. 2002. Seasonality extraction by function fitting to time-series of satellite sensor data[J]. IEEE 
Transactions on Geoscience and Remote Sensing, 40(8): 1824-1832.

Moulin S, Kergoat L, Viovy N, et al. 1997. Global-scale assessment of vegetation phenology using NOAA/AVHRR satellite measurements[J]. Journal of Climate, 10(6): 1154-1170.

Myneni R B, Keeling C D, Tucker C J, et al. 1997. Increased plant growth in the northern high latitudes from 1981 to 1991[J]. Nature, 386: 698-702.

Peñuelas J, Filella I. 2001. Responses to a warming world[J]. Science, 294: 793-795.

Piao S L, Fang J Y, Zhou L M, et al. 2006. Variations in satellite- derived phenology in China's temperate vegetation [J]. Global Change Biology, 12(4): 672-685.
Roerink G J, Menenti M, Verhoef W. 2000. Reconstructing cloudfree NDVI composites using Fourier analysis of time series[J]. International Journal of Remote Sensing, 21(9): 1911-1917.

Schwartz M D. 2003. Phenology: an integrative environmental science $[\mathrm{M}]$. Kluwer, Netherlands: Springer.

White M A, de Beurs K M, Didan K, et al. 2009. Intercomparison, interpretation, and assessment of spring phenology in North America estimated from remote sensing for 19822006[J]. Global Change Biology, 15(10): 2335-2359.

White M A, Hoffman F, Hargrove W W, et al. 2005. A global framework for monitoring phenological responses to climate change[J]. Geophysical Research Letters, 32(4): L04705.

\title{
Spatiotemporal variations of forest phenology in the Qinling zone based on remote sensing monitoring, 2001-2010
}

\author{
XIA Haoming $^{1,2}$, LI Ainong $^{1^{*}}$, ZHAO Wei $^{1}$, BIAN Jinhu ${ }^{1,2}$, LEI Guangbin ${ }^{1,2}$ \\ (1. Institute of Mountain Hazards and Environment, CAS, Chengdu 610041, China; \\ 2. University of Chinese Academy of Sciences, Beijing 100049, China)
}

\begin{abstract}
Plant phenology is one of the most salient and sensitive indicators of terrestrial ecosystem's response to climate change. Understanding its spatiotemporal change is significantly important for understanding both land surface processes and carbon cycle and predicting changes in the terrestrial ecosystem. MODIS MOD09A1, with the spatial resolution of $500 \mathrm{~m} \times 500 \mathrm{~m}$ and at an 8-day temporal interval, was used in this study to investigate the change in forest phenology in the Qinling zone of central China in 2001-2010. First, we used the day of year (DOY) of MOD09A1 to improve the temporal precision of EVI; we then combined the maximum ratio and the threshold method for phenology data extraction [start of growth season (SOG), end of growth season (EOG), and length of growth season (LOG)] in the Qinling zone. Results of this study show that: Accompanying the deterioration in heat and water conditions from low altitude to high altitude and southeast to northwest, SOG delayed, EOG advanced, and LOG shortened gradually. SOG and EOG mainly occurred on the 81th-120th and 270th-311th days respectively. LOG was mainly between 150 and 230 days. The phenology of forest in Qinling zone is closely related to altitude, with every $100 \mathrm{~m}$ rising in altitude, SOG, EOG, and LOG gradualy delayed 2 days, advanced 1.9 days, and shortened 3.9 days, respectively. From 2001 to 2010, early SOG, late EOG, and extended LOG mainly occurred in medium altitude. SOG, EOG, and LOG gradually delayed, advanced, and shortened respectively in some areas that are lowered than 1,000 $\mathrm{m}$ above sea level. Interannual changes at high altitude were more complicated than that at low altitude, and SOG advanced, EOG advanced, and LOG shortened above $2000 \mathrm{~m}$. The reasons for these changes remain unclear. The findings quantified the differences of forest phenology with the change in elevation and revealed the spatiotemporal variations in forest phenology from 2001 to 2010. This article provides a reference for the evaluation and protection of ecological environment in the Qinling zone. In future study, reasons for the above mentioned differences in forest phenology need to be explored.
\end{abstract}

Key words: EVI; HANTS; phenology; spatiotemporal variation; Qinling zone 